the soil core. Root, detrital and soil carbon content were determined by combustion/gas chromatography (Europea Scientific); combustion/gas chromatographic determinations of shoot carbon content values from the peak biomass harvest in 1992 were used to calculate shoot carbon pools. Microbial carbon content was determined by chloroform fumigation.

Microcosm experiment. Seeds of plants representative of the serpentine and sandstone grassland communities were planted in $0.4-\mathrm{m}$ diameter tubes with a 0.95-m deep column of serpentine soil in September-October 1992 and grown in open-top enclosures supplied with ambient ( 360 p.p.m.) or elevated (720 p.p.m.) $\mathrm{CO}_{2}$. By the second growing season, all were similar in plant species composition and ecosystem properties, and so are combined for presentation and analysis. Nitrogen, phosphorus and potassium $\left(20 \mathrm{~g} \mathrm{~m}^{-2}\right)$ were supplied once each season as a slow-release fertilizer to half of the tubes in a factorial design. In mid-March 1993, a subset of the tubes was pulse labelled by closing the chambers and supplying 1 litre of $99 \%{ }^{13} \mathrm{CO}_{2}$ to the chamber atmosphere during a 5-h period (8:00 to 13:00). At the height of flowering the following year (18-20 April 1994), we determined the $\delta^{13} \mathrm{C}$ of soil $\mathrm{CO}_{2}$ $\left({ }^{13} \mathrm{CO}_{2} \mathrm{BR}\right)$ collected from perforated stainless steel tubes inserted into the soil $(0-15 \mathrm{~cm}$ depth $)$ and the amount and $\delta^{13} \mathrm{C}$ of $\mathrm{CO}_{2}$ produced by soil heterotrophs during 96-h laboratory incubations of root-free soil $\left({ }^{13} \mathrm{CO}_{2}\right.$ $\mathrm{HR})$. We assumed that root $\delta^{13} \mathrm{C}$ was the same as the $\delta^{13} \mathrm{C}$ of $\mathrm{CO}_{2}$ produced by root respiration $\left({ }^{13} \mathrm{CO}_{2} \mathrm{RR}\right)$ and calculated the proportional contributions from roots $(y)$ and soil heterotrophs $(1-y)$ to below-ground respiration: ${ }^{13} \mathrm{CO}_{2} \mathrm{BR}=y\left({ }^{13} \mathrm{CO}_{2} \mathrm{RR}\right)+(1-y)\left({ }^{13} \mathrm{CO}_{2} \mathrm{HR}\right)$. We also calculated root respiration by difference, as below-ground respiration rates ${ }^{22}$ minus $\mathrm{CO}_{2}$ production rates in the soil incubations. The ${ }^{13} \mathrm{C}$ signal associated with the $\mathrm{CO}_{2}$ enrichment of the atmosphere and the pulse label allowed us further to partition the heterotrophic respiration flux into three components. The soil organic carbon (SOC) contribution to heterotrophic respiration (HR) was calculated using the elevated $\mathrm{CO}_{2}$ treatment with no pulse label, where $x$ is the proportional contribution of SOC to HR: ${ }^{13} \mathrm{CO}_{2} \mathrm{HR}=x\left({ }^{13} \mathrm{C} \mathrm{SOC}\right)+(1-x)\left({ }^{13} \mathrm{C}\right.$ plant $)$. Rhizodeposition and previous year's litter contributions to $\mathrm{HR}$ were calculated using ambient and elevated $\mathrm{CO}_{2}$ treatments that had been pulse labelled, where $y$ is the proportional contribution of rhizodeposition to HR and $x$ is from above: ${ }^{13} \mathrm{CO}_{2} \mathrm{HR}=x\left({ }^{13} \mathrm{C}\right.$ SOC $)+y\left({ }^{13} \mathrm{C}\right.$ rhizodeposition $)+(1-x-y)\left({ }^{13} \mathrm{C}\right.$ litter $)$.

Received 10 January; accepted 9 June 1997.

. Schimel, D. et al. in Climate Change 1995: The Science of Climate Change (eds Houghton, J. T. et al.) 65-131 (Cambridge Univ. Press, 1996).

2. Long, S. P. \& Drake, B. G. in Topics in Photosynthesis (eds Baker, N. R. \& Thomas, H.) 69-107 (Elsevier, Amsterdam, 1992)

3. Broecker, W. S., Takahashi, T., Simpson, H. J. \& Peng, T. H. Fate of fossil fuel carbon dioxide and the global carbon budget. Science 206, 409-418 (1979)

4. Gifford, R. M. Carbon dioxide and plant growth under water and light stress, implications for balancing the global carbon budget. Search 10, 316-318 (1979).

5. Drake, B. G. \& Leadley, P. W. Canopy photosynthesis of crops and native plants exposed to long-term elevated $\mathrm{CO}_{2}$ : commissioned review. Plant Cell Env. 14, 853-860 (1991).

6. Canadell, J. G., Pitelka, L. F. \& Ingram, J. S. I. The effects of elevated $\mathrm{CO}_{2}$ on plant-soil carbon below ground: a synthesis. Plant Soil 187, 391-400 (1996).

7. Schimel, D. S. Terrestrial ecosystems and the carbon cycle. Global Change Biol. 1, 77-91 (1995).

8. Harrison, K., Broecker, W. \& Bonani, G. A strategy for estimating the impact of $\mathrm{CO}_{2}$ fertilisation on soil carbon storage. Global Biogeochem. Cycles 7, 69-80 (1993).

9. Hilbert, D. W., Larigauderie, A. \& Reynolds, J. F. The influence of carbon dioxide and daily photonflux density on optimal leaf nitrogen concentration and root:shoot ratio. Ann. Bot. 68, 365-376 (1991).

10. Luo, Y., Field, C. B. \& Mooney, H. A. Predicting responses of photosynthesis and root fraction to elevated $\mathrm{CO}_{2}$ : Interactions among carbon, nitrogen, and growth. Plant Cell Env. 17, 1195-1204 (1994).

11. Field, C. B., Chapin, F. S. III, Matson, P. A. \& Mooney, H. A. Responses of terrestrial ecosystems to the changing atmosphere: A resource-based approach. Annu. Rev. Ecol. Syst. 23, 201-235 (1992).

12. van Veen, J. A., Liljeroth, E. L., Lekkerkerk, J. A. \& van de Geijn, S. C. Carbon fluxes in plant-soil systems at elevated atmospheric $\mathrm{CO}_{2}$ levels. Ecol. Appl. 2, 175-181 (1991).

13. van de Geijn, S. C. \& van Veen, J. A. Implications of increased carbon dioxide levels for carbon input and turnover in soils. Vegetatio 104/105, 283-292 (1993).

14. Stulen, I. \& den Hertog, J. Root growth and functioning under atmospheric $\mathrm{CO}_{2}$ enrichment. Vegetatio 104/105, 99-115 (1993)

15. Rogers, H. H., Runion, G. B. \& Krupa, S. V. Plant responses to atmospheric $\mathrm{CO}_{2}$ enrichment with emphasis on roots and the rhizosphere. Env. Pollut. 83, 155-189 (1994).

16. Norby, R. J. Issues and perspectives for investigating root responses to elevated atmospheric carbon dioxide. Plant Soil 165, 9-20 (1994).

17. Hickman, J. C. The Jepson Manual: Higher Plants of California (Univ. California Press, Berkeley, 1993).

18. Field, C. B., Chapin, F. S. III, Chiariello, N. R., Holland, E. A. \& Mooney, H. A. in Carbon Dioxide and Terrestrial Ecosystems (eds Koch, G. W. \& Mooney, H. A.) 121-145 (Academic, Sand Diego, 1996).

19. Jackson, R. B., Sala, O. E., Field, C. B. \& Mooney, H. A. $\mathrm{CO}_{2}$ alters water use, carbon gain, and yield for the dominant species in a natural grassland. Oecologia 98, 257-262 (1994).

20. Hungate, B. A., Jackson, R. B., Field, C. B. \& Chapin, F. S. III Detecting changes in soil carbon in $\mathrm{CO}_{2}$ enrichment experiments. Plant Soil 187, 135-145 (1996).

21. Thompson, M. V., Randerson, J. T., Malmström, C. M. \& Field, C. B. Change in net primary production and heterotrophic respiration: how much is necessary to sustain the terrestrial sink? Global Biogeochem. Cycles 10, 711-726 (1996).

22. Luo, Y., Jackson, R. B., Field, C. B. \& Mooney, H. A. Elevated $\mathrm{CO}_{2}$ increases belowground respiration in California grasslands. Oecologia 108, 130-137 (1996).

23. Raich, J. W. \& Nadelhoffer, K. J. Belowground carbon allocation in forest ecosystems: global trends. Ecology 70, 1346-1354 (1989).

24. Higgins, P. A. T. thesis, Stanford Univ. (1996).

25. Chiariello, N. R. \& Field, C. B. in Community, Population and Evolutionary Responses to Elevated Carbon Dioxide Concentration (eds Körner, C. \& Bazzaz, F. A.) 139-175 (Academic, San Diego, 1996).

26. Drake, B. G. et al. Acclimation of photosynthesis, respiration, and ecosystem carbon flux of wetland on Chesapeake Bay, Maryland, to elevated atmospheric $\mathrm{CO}_{2}$ concentrations. Plant Soil 187, 111-118 (1996).

27. Parton, W. J., Schimel, D. S., Cole, C. V. \& Ojima. Analysis of factors controlling soil organic matter levels in Great Plains grasslands. Soil Sci. Soc. Am. J. 51, 1173-1179 (1987).

28. Oades, J. M. The retention of organic matter in soils. Biogeochemistry 5, 35-70 (1988).

29. Parton, W. J. et al. Impact of climate change on grassland production and soil carbon worldwide. Global Change Biol. 1, 13-22 (1995).

30. Ham, J. M., Owensby, C. E., Coyne, P. I. \& Bremer, D. J. Fluxes of $\mathrm{CO}_{2}$ and water vapor from a prairie ecosystem exposed to ambient and elevated atmospheric $\mathrm{CO}_{2}$. Agric. For. Meteorol. 77, 73-93 (1995).

Acknowledgements. We thank N. Chiariello, C. Chu, G. Joel, Y. Luo, B. Mortimer, E. Nelson, J. Randerson, H. Reynolds, J. des Rosier, S. Thayer and J. Whitbeck for contributions to the design and execution of the experiment; $\mathrm{H}$. Whitted for help with experimental design and construction; P. Canadell, Z. Cardon, R. Martin and A. Townsend for assistance and advice with the ${ }^{13} \mathrm{CO}_{2}$ labelling, sampling and interpretation; I. Sulzman for help with the figures; and D. Schimel for help with the isotope calculations. The Jasper Ridge $\mathrm{CO}_{2}$ experiment is supported by grants from the US NSF to the Carnegie Institution of Washington, Stanford University and the University of California, Berkeley. B.A.H. was supported by a Washington, Stanford University and the University of California, Berkeley. B.A.H. was supported by a
National Defense Science and Engineering graduate fellowship and an NSF doctoral dissertation improvement grant. R.B.J. was supported by a grant from NIGEC/DOE and a DOE distinguished postdoctoral fellowship for global change. The National Center for Atmospheric Research is sponsored by the NSF. This is publication number 1344 from the Carnegie Institution of Washington, Department of Plant Biology.

Correspondence and requests for materials should be addressed to B.A.H. (e-mail: hungate@serc.si.edu).

\section{Net transfer of carbon between ectomycorrhizal tree species in the field}

\author{
Suzanne W. Simard ${ }^{\star}$, David A. Perry $\dagger$, \\ Melanie D. Jones $\ddagger$, David D. Myrold\$, \\ Daniel M. Durall $\ddagger$ \& Randy Molina\|
}

* Kamloops Forest Region, British Columbia Ministry of Forests, Kamloops, British Columbia V2C 2T7, Canada

$\dagger$ Forest Science Department and \$Crop and Soil Science Department,

Oregon State University, Corvallis, Oregon 97331, USA

$\ddagger$ Biology Department, Okanagan University College, Kelowna, British Columbia V1V 1 V7, Canada

\| United States Department of Agriculture, Forest Service, Pacific Northwest

Research Station, Corvallis, Oregon 97331, USA

Different plant species can be compatible with the same species of mycorrhizal fungi ${ }^{1,2}$ and be connected to one another by a common mycelium ${ }^{3,4}$. Transfer of carbon $^{3-5}$, nitrogen ${ }^{6,7}$ and phosphorus $^{8,9}$ through interconnecting mycelia has been measured frequently in laboratory experiments, but it is not known whether transfer is bidirectional, whether there is a net gain by one plant over its connected partner, or whether transfer affects plant performance in the field ${ }^{10,11}$. Laboratory studies using isotope tracers show that the magnitude of one-way transfer can be influenced by shading of 'receiver' plants ${ }^{3,5}$, fertilization of 'donor' plants with phosphorus ${ }^{12}$, or use of nitrogen-fixing donor plants and non-nitrogen-fixing receiver plants ${ }^{13,14}$, indicating that movement may be governed by source-sink relationships. Here we use reciprocal isotope labelling in the field to demonstrate bidirectional carbon transfer between the ectomycorrhizal tree species Betula papyrifera and Pseudotsuga menziesii, resulting in net carbon gain by $P$. menziesii. Thuja plicata seedlings lacking ectomycorrhizae absorb small amounts of isotope, suggesting that carbon transfer between $B$. papyrifera and $P$. menziesii is primarily through the direct hyphal pathway. Net gain by $P$. menziesii seedlings represents on average $6 \%$ of carbon isotope uptake through photosynthesis. The magnitude of net transfer is influenced 
by shading of $P$. menziesii, indicating that source-sink relationships regulate such carbon transfer under field conditions.

Plants within communities can be interconnected and exchange resources through a common hyphal network ${ }^{1-14}$, and form guilds based on their shared mycorrhizal associates ${ }^{15-17}$. Consequently, the theory that plant community dynamics operate mainly within the constraints of resource supply ${ }^{18}$ should be reformulated to consider mutualism between plants and their mycorrhizal fungi, as well as microbially mediated resource sharing ${ }^{15,17,19}$.

We have studied shared compatibility of ectomycorrhizal fungi and interspecific carbon transfer in Betula papyrifera Marsh. and Pseudotsuga menziesii (Mirb.) Franco. Seven ectomycorrhizal morphotypes were common between $B$. papyrifera and $P$. menziesii, covering over $90 \%$ of their root tips, indicating a high potential for interspecific hyphal connections ${ }^{20}$. We used reciprocal labelling with ${ }^{13} \mathrm{C}$ and ${ }^{14} \mathrm{C}$ in the field to examine below-ground transfer between the two tree species. To our knowledge, this is the first study in which reciprocal labelling has been used to investigate bidirectional and net carbon transfer.

We examined carbon transfer during two growing seasons, when seedlings planted in forest soil were two or three years old. Ectomycorrhizal B. papyrifera and P. menziesii and vesiculararbuscular (VA) mycorrhizal Thuja plicata D. Don. were planted $0.5 \mathrm{~m}$ apart in three-seedling groups. These three tree species occur naturally together in the experimental area. Thuja plicata served as a marker for indirect isotope movement through soil pathways (that is, in respired gaseous $\mathrm{CO}_{2}$, exudates, and sloughed root and fungal cells). Four or six weeks before labelling, P. menziesii seedlings in the replicate groups were exposed to three light treatments: deep shade, partial shade, and full ambient sunlight (Table 1). After the shading period, B. papyrifera and $P$. menziesii in each group were pulselabelled with gaseous ${ }^{13} \mathrm{CO}_{2}$ or ${ }^{14} \mathrm{CO}_{2}$. This approach enabled detection of the carbon isotope that was received by one seedling from the other. Reciprocal labelling schemes were applied to replicate seedling groups in the first year to account for differences in absolute isotope fixation between ${ }^{13} \mathrm{C}$ and ${ }^{14} \mathrm{C}$. Pulse-labelling for $2 \mathrm{~h}$ in full ambient light with a minimum photosynthetically active radiation level of $800 \mu \mathrm{mol} \mathrm{m}^{-2} \mathrm{~s}^{-1}$ was followed by a 9-day chase period under the light treatments. Seedlings were then harvested and separated into foliage, stems, coarse roots and fine roots. Ground tissue was combusted to $\mathrm{CO}_{2}$ and analysed for ${ }^{13} \mathrm{C}$ abundance by mass spectrometry and ${ }^{14} \mathrm{C}$ by liquid scintillation.

Carbon transfer between B. papyrifera and P. menziesii occurred in both directions in the first and second year, and, although there was no net transfer in the first year, there was a net gain in carbon by P. menziesii in all three light intensities in the second year (Table 1 and Fig. 1). In the first year (two-year-old seedlings), isotope transfer to $P$. menziesii was balanced by reciprocal transfer to B. papyrifera (so there was no net transfer) in all light intensities ( $P=0.10$ for light treatment effects). Bidirectional transfer between B. papyrifera and $P$. menziesii represented $4 \%$ of total isotope fixed by both species together, and transfer through soil pathways to T. plicata was $<1 \%$ of the total transfer between the ectomycorrhizal species $^{20}$.

In the second year (three-year-old seedlings), net transfer to $P$. menziesii and bidirectional transfer between B. papyrifera and $P$. menziesii represented on average $6 \%$ and $7 \%$, respectively, of the total isotope fixed by the two tree species together, and both were over twice as great in deep shade as in partial shade or full light $(P<0.05$; Table 1 and Fig. 1$)$. Transfer to VA mycorrhizal T. plicata averaged $18 \%$ of the total transfer between B. papyrifera and $P$. menziesii, suggesting that most transfer between the ectomycorrhizal tree species occurred through hyphal connections ${ }^{20}$. The greater effect of shading on magnitude of bidirectional transfer and the occurrence of net transfer in the second rather than the first experiment year coincided with greater root extension and potential for interplant hyphal linkages, as well as increased vigour of

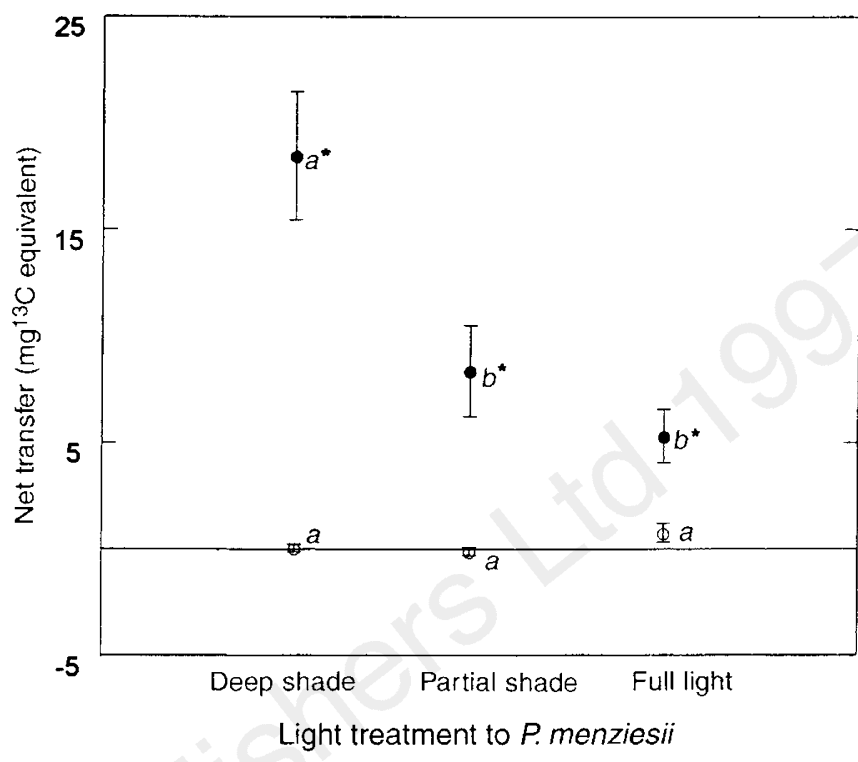

Figure 1 Mean ( \pm s.e.) net transfer from B. papyrifera to P. menziesii in deep shade, partial shade and full ambient sunlight in the first (two-year-old seedlings, open circles) and second (three-year-old seedlings, filled circles) experiment years. Within years, means denoted by the same letter ( $a$ or $b$ ) do not differ significantly $(P<0.05)$. Asterisks indicate treatments in which net transfer was greater than zero $(P<0.05)$.

seedlings in the second year, and indicates that transfer varies according to seedling status and environmental conditions.

The greater transfer in deep shade in the second year was due to increased transfer from $B$. papyrifera to $P$. menziesii, indicating that net transfer was affected by changes in the sink strength of P. menziesii. Net transfer from B. papyrifera to P. menziesii was associated with whole-seedling net photosynthetic rates 1.5 and 4.3 times greater for B. papyrifera than for P. menziesii in full light and deep shade, respectively, and foliar nitrogen concentrations twice as great for $B$. papyrifera as for $P$. menziesii ${ }^{20}$. These results suggest that carbon was transferred between species down carbon and nitrogen gradients. Fully developed leaves are strong sinks for nitrogen and are sources rather than sinks for carbon ${ }^{21}$, and amino acids rather than sugars have been shown to pass from ectomycorrhizal fungi into host plants ${ }^{22,23}$. Consequently, it has been suggested that transfer may be regulated more strongly by a nitrogen gradient than a carbon gradient $t^{6,22}$.

The $3-10 \%$ net transfer from $B$. papyrifera to $P$. menziesii measured in these experiments represents a substantial carbon gain by $P$. menziesii. It is similar to the $10 \%{ }^{14} \mathrm{C}$ transfer one way from clonal parent plants to connected ramets that has been suggested to be of sufficient magnitude to increase survival and growth of the ramets ${ }^{24}$. It is also similar to the $5-15 \%$ transfer of fixed gaseous ${ }^{15} \mathrm{~N}_{2}$ from Alnus glutinosa to Pinus contorta through ectomycorrhizal connections ${ }^{6}$, and to the $0-10 \%$ of carbon in Cynodon dactylon roots that was derived from Plantago lanceolata through VA mycorrhizal connections ${ }^{25}$. Carbon transfer of this magnitude, especially if it is associated with nitrogen, would be expected to affect performance under critically harsh conditions or over the lifetime of a P. menziesii seedling ${ }^{10,11}$.

In our experiments, the average amount of received isotope that was retranslocated from roots to foliage was $13 \%$ for $P$. menziesii and $45 \%$ for B. papyrifera. The amounts retranslocated from roots to foliage of receivers exceed those observed in previous ectomycorrhizal carbon-transfer experiments (usually $<10 \%)^{5,10}$, and could either supplement photosynthate or, if carbon is transferred as amino acids, the foliar nitrogen pools ${ }^{23}$. The pattern of carbon 


\begin{tabular}{|c|c|c|c|c|c|}
\hline $\begin{array}{l}\text { Light treatments } \\
\text { to } P \text {. menziesii }\end{array}$ & $\begin{array}{l}\text { PAR incident on } \\
\text { P. menziesii } \\
\left(\mu \mathrm{mol} \mathrm{m}^{-2} \mathrm{~s}^{-1}\right)^{\star}\end{array}$ & $\begin{array}{l}\text { Whole-seedling net } \\
\text { photosynthetic rate of } \\
\text { P. menziesii }\left(\mu \mathrm{mol} \mathrm{s}^{-1}\right)\end{array}$ & $\begin{array}{l}\text { Bidirectional carbon transfer } \\
\quad \text { (mg }{ }^{13} \mathrm{C} \text { equivalent) }\end{array}$ & $\begin{array}{l}\text { Bidirectional transfer as \% of } \\
\text { total isotope in donor } \\
\text { B. papyrifera + P. menziesii }\end{array}$ & $\begin{array}{l}\text { Net carbon transfer as \% of } \\
\text { total isotope in donor } \\
\text { B. papyrifera + P. menziesii }\end{array}$ \\
\hline \multicolumn{6}{|c|}{ Two-year-old seedlings } \\
\hline deep shade & $15 \pm 5 c$ & $0.012 \pm 0.002 b$ & $0.97 \pm 0.29 a$ & 2.7 & 0.1 \\
\hline partial shade & $75 \pm 5 b$ & $0.021 \pm 0.005 a$ & $1.19 \pm 0.20 a$ & 2.6 & -0.3 \\
\hline full ambient light & $175 \pm 7 a$ & $0.023 \pm 0.023 a$ & $2.13 \pm 0.59 a$ & 6.9 & 2.4 \\
\hline \multicolumn{6}{|c|}{ Three-year-old seedlings } \\
\hline deep shade & $60 \pm 10 c$ & $0.05 \pm 0.01 b$ & $22.06 \pm 2.88 a$ & 10.7 & 9.5 \\
\hline partial shade & $250 \pm 60 b$ & $0.18 \pm 0.04 a$ & $10.87 \pm 2.04 b$ & 5.3 & 4.3 \\
\hline full ambient light & $1,330 \pm 50 a$ & $0.14 \pm 0.03 a$ & $7.98 \pm 1.65 b$ & 3.9 & 2.7 \\
\hline
\end{tabular}

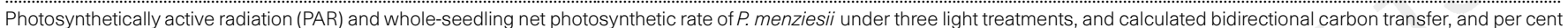

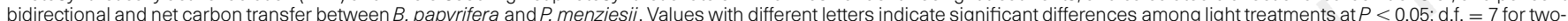
bidirectional and net carbon transfer between $B$. papyrifera and $P$. menziesii. Values with
year-old seedlings, and d.f. $=4$ for three-year-old seedlings. Values are mean \pm s.e..

* PAR and net photosynthetic rate were measured on a uniformly cloudy day in the first year (two-year-old seedlings) and a sunny day in the second year (three-year-old seedlings).

transfer in these ectomycorrhizal plants therefore contrasts with that reported for some VA mycorrhizal systems, where relatively little of the transferred carbon was onwardly mobilized into shoots of receiver plants, and may represent carbon restricted to fungal tissue in roots of receiver plants ${ }^{3,25,26}$.

The amount of carbon exchanged between B. papyrifera and $P$. menziesii is indicative of a tightly linked plant-fungus-soil system. Our study extends earlier laboratory results ${ }^{3-6,10,11,24,25}$ to the field, providing direct evidence for both bidirectional and net carbon transfer between plant species, for the occurrence of hyphal as well as soil pathways, and for source-sink regulation of net transfer in field conditions. When $P$. menziesii seedlings are establishing and growing in the shade of illuminated B. papyrifera in natural, mixed communities, they may benefit directly from their association with B. papyrifera through supplemental gains in transferred carbon. There is a further possibility that carbon is distributed belowground among plants across resource gradients, other than light, that affect relative photosynthetic potential within a mycorrhizally linked plant community. Such a mechanism would offer one explanation for the ability of species-rich communities to maintain productivity during drought or where nutrients are limiting ${ }^{27}$. If our results reflect the magnitude of carbon transfer in natural systems, then the net competitive effect of one species on another cannot be predicted without a better understanding of interplant carbon transfer through shared mycorrhizal fungi and soil pathways. A more even distribution of carbon among plants as a result of belowground transfer may have implications for local interspecific interactions ${ }^{28}$, maintenance of biodiversity ${ }^{11,15,17}$, and therefore for ecosystem productivity, stability and sustainability ${ }^{16,19,27}$.

\section{Methods}

Seedling groups. In both experiment years, each experimental unit consisted of a seedling group. In the first year (two-year-old seedlings), a $3 \times 2$ factorial set of treatments was replicated four times in a completely randomized design (24 experimental units). The treatments consisted of three P. menziesii light treatments (full ambient light, partial shade and deep shade) and two labelling schemes $\left({ }^{14} \mathrm{C}-B\right.$. papyrifera with ${ }^{13} \mathrm{C}-P$. menziesii; ${ }^{13} \mathrm{C}$ - B . papyrifera with ${ }^{14} \mathrm{C}-P$. menziesii). In the second year (three-year-old seedlings), each of the three light treatments was applied to five replicate groups of seedlings in a completely randomized design ( 15 experimental units). Owing to a shortage of replicate seedling groups, only one labelling scheme was applied in the second year: ${ }^{14} \mathrm{C}-B$. papyrifera with ${ }^{13} \mathrm{C}-P$. menziesii.

Light treatments. In the partial and deep shade treatments, $P$. menziesii seedlings were shaded with lightly and heavily clothed cone-shaped tents four weeks before labelling on 14-16 July 1993 (first year), and six weeks before labelling on 4-5 August 1994 (second year). The shade tents were removed from $P$. menziesii during the 2-h pulse for maximum labelling efficiency. Each B. papyrifera and $P$. menziesii seedling was sealed inside flexible, airtight, 5-mm thick $\times 60-\mathrm{cm}$ wide $\times 90-\mathrm{cm}$ tall fluoropolymer gas sampling bags (Norton Performance Plastics). The shoot of one partner seedling was then pulsed with $200 \mathrm{ml}$ gaseous ${ }^{13} \mathrm{CO}_{2}\left(99 \%\right.$, equivalent to $107.42 \mathrm{mg}{ }^{13} \mathrm{C}$ ), and the shoot of the other partner was pulsed with 7.4 MBq gaseous ${ }^{14} \mathrm{CO}_{2}$ (equivalent to $52.86 \mu \mathrm{g}$ ${ }^{14} \mathrm{C}$, released from $\mathrm{Na}_{2}{ }^{14} \mathrm{CO}_{3}$ with lactic acid).

Bidirectional and net transfer calculations. Sample $\delta^{13} \mathrm{C}(\% 0)$ and ${ }^{14} \mathrm{C}(\mathrm{Bq})$ values were converted to excess carbon isotope $(\mathrm{mg})$ for bidirectional and net transfer calculations. The conversions were based on previously described procedures ${ }^{29,30}$. Conversion of $\delta^{13} \mathrm{C}(\%)$ to the absolute isotope ratio $\left({ }^{13} \mathrm{C} /{ }^{12} \mathrm{C}\right)$ of the sample was based on the PeeDee Belemnite (PDB) standard. Fractional abundance $\left({ }^{13} \mathrm{C} /\left({ }^{13} \mathrm{C}+{ }^{12} \mathrm{C}\right)\right)$ and total carbon content $(\mathrm{mg})$ of the sample were used to calculate ${ }^{13} \mathrm{C}$ content $(\mathrm{mg})$ of the sample. Conversion of ${ }^{14} \mathrm{C}(\mathrm{Bq})$ to ${ }^{14} \mathrm{C}$ content $(\mathrm{mg})$ was based on the batch-specific activity $(\lambda)$ of $\mathrm{Na}_{2}{ }^{14} \mathrm{CO}_{2}$ $\left(\lambda=1.96 \mathrm{GBq} \mathrm{mmol}^{-1}\right.$; Amersham Canada). Excess isotope $\left({ }^{13} \mathrm{C}\right.$ or $\left.{ }^{14} \mathrm{C}\right)$ content $(\mathrm{mg})$ of the tissue was calculated as the product of excess isotope content of the sample and tissue biomass, and excess isotope $(\mathrm{mg})$ of the whole plant was determined by summing excess isotope content of the four tissue types. Bidirectional and net transfer calculations were based on whole-plant levels of excess isotope that were received from partner donor seedlings. Bidirectional transfer was the sum of isotope received by both $P$. menziesii and B. papyrifera in a seedling group. Conversely, net transfer was the difference between isotope received by $P$. menziesii and that received by $B$. papyrifera. Positive net transfer indicated that a greater amount of isotope was received by P. menziesii than by B. papyrifera, and negative net transfer indicated the opposite. Bidirectional and net transfer were expressed as proportions of total isotope assimilated by $P$. menziesii and B. papyrifera together.

Statistical analysis. Significant labelling scheme effects in the first year were detected using two factor analysis of variance (ANOVA) ( $\alpha$ set at 0.05 ). For calculations of bidirectional and net carbon transfer, labelling scheme effects were first removed by applying correction factors to excess ${ }^{14} \mathrm{C}$ content $(\mathrm{mg})$ on a treatment-species-tissue basis. The correction factors were the speciestissue-specific ratios of excess ${ }^{13} \mathrm{C}(\mathrm{mg})$ to excess ${ }^{14} \mathrm{C}(\mathrm{mg})$ measured in the reciprocal labelling schemes of the same light treatment. The treatmentspecies-tissue-specific correction factors were averaged over the four replicates per labelling scheme in the first year. The correction factors derived in the first year were applied to data collected in the second year, because only one labelling scheme was applied in the second year. Using the corrected excess ${ }^{14} \mathrm{C}$ values (analogous to excess ${ }^{13} \mathrm{C}$ equivalent values), data from the first and second years were subject to one-factor ANOVA for comparisons of net and bidirectional transfer among $P$. menziesii light treatments ( 7 degrees of freedom for the first year, 4 for the second). Net transfer estimates were compared with zero using $t$-tests.

Received 24 April; accepted 16 May 1997

1. Molina, R., Massicotte, H. \& Trappe, J. M. in Mycorrhizal Functioning: An Integrative Plant-Fungal Progess (ed. Allen, M. F.) 357-423 (Chapman and Hall, New York, 1992)

2. Massicotte, H. G., Molina, R., Luoma, D. L. \& Smith, J. E. Biology of the ectomycorrhizal genus, Rhizopogon. II. Patterns of host-fungus specificity following spore inoculation of diverse hosts grown in monoculture and dual culture. New Phytol. 126, 677-690 (1994).

3. Francis, R. \& Read, D. J. Direct transfer of carbon between plants connected by vesicular-arbuscular mycorrhizal mycelium. Nature 307, 53-56 (1984).

4. Brownlee, C., Duddridge, J. A., Malibari, A. \& Read, D. J. The structure and function of ectomycorrhizal roots with special reference to their role in forming interplant connections and providing pathways for assimulate and water transport. Plant Soil 71, 433-443 (1983).

5. Finlay, R. \& Read, D. J. The structure and function of the vegetative mycelium of ectomycorrhizal plants. I. Translocation of ${ }^{14} \mathrm{C}$-labeled carbon between plants interconnected by a common mycelium. New Phytol. 103, 143-156 (1986).

6. Arnebrant, K., Ek, H., Finlay, R. D. \& Soderstrom, B. Nitrogen translocation between Alnus glutinosa 
(L.) Gaertn. seedlings inoculated with Frankia sp. and Pinus contorta Doug. ex Loud seedlings connected by a common ectomycorrhizal mycelium. New Phytol. 130, 231-242 (1993).

7. Bethlenfalvay, G. J., Reyes-Solis, M. G., Camel, S. B. \& Ferrera-Cerrato, R. Nutrient transfer between the root zones of soybean and maize plants connected by a common mycorrhizal mycelium. Physiologia Plantarum 82, 423-432 (1991).

8. Newman, E. I. \& Eason, W. R. Rates of phosphorus transfer within and between ryegrass (Lolium perenne) plants. Funct. Ecol. 7, 242-248 (1993).

9. Wittingham, J. \& Read, D. J. Vesicular-arbascular mycorrhiza in natural vegetation systems III. Nutrient transfer between plants with mycorrhizal connections. New Phytol. 90, 277-284 (1982).

10. Newman, E. I. Mycorrhizal links between plants: their functioning and ecological significance. $A d v$ Ecol. Res. 18, 243-270 (1988)

11. Miller, S. L. \& Allen, E. B. in Mycorrhizal Functioning: An Integrative Plant-Fungal Process (ed. Allen, M. F.) 301-332 (Chapman and Hall, New York, 1992).

12. Ritz, K. \& Newman, E. I. Nutrient transport between ryegrass plants differing in nutrient status. Oecologia 70, 128-131 (1986).

13. Frey, B. \& Schüepp. H. Transfer of symbiotically fixed nitrogen from berseem (Trifolium alexandrium L.) to maize via vesicular arbuscular mycorrhizal hyphae. New Phytol. 125, 447-454 (1992).

14. Ekblad, A. \& Huss-Danell, K. Nitrogen fixation by Alnus incana and nitrogen transfer from A. incana to Pinus sylvestris influenced by macronutrients and ectomycorrhiza. New Phytol. 131, 453-459 (1995).

15. Perry, D. A., Bell, T. \& Amaranthus, M. P. in The Ecology of Mixed-Species Stands of Trees (eds Cannell, M. G. R., Malcom, D. C. \& Robertson, P. A.) 151-179 (Cambridge Univ. Press, 1992).

16. Perry, D. A., Amaranthus, M. P., Borchers, J. G., Borchers, S. L. \& Brainerd, R. E. Bootstrapping in ecosystems. Bioscience 39, 230-237.

17. Read, D. J. in Biodiversity and Ecosystem Function (eds Schulze, E.-D. \& Mooney, H. A.) 181-209 (Springer, Berlin, 1994).

18. Tilman, D. Dynamics and Structure of Plant Communities (Princeton Univ. Press, NJ, 1988).

19. Shulze, E.-D. \& Mooney, H. A. in Biodiversity and Ecosystem Function (eds Schulze, E.-D. \& Mooney H. A.) 497-510 (Springer, Berlin, 1994)

20. Simard, S. W. thesis, Oregon State Univ. (1995).

21. Pearcy, R. W. et al. Carbon gain by plants in natural environments. Bioscience 37, 21-28 (1987).

22. Smith, S. E. \& Smith, F. A. Structure and function of the interfaces in biotrophic symbioses as they relate to nutrient transport. New Phytol. 114, 1-38 (1990).

23. Abuzinadah, R. A. \& Read, D. J. Carbon transfer associated with assimilation of organic nitrogen sources by silver birch (Betula pendula Roth.). Trees 3, 17-23 (1989).

24. Alpert, P., Warembourg, F. R. \& Roy, J. Transport of carbon among connected ramets of Eichhornia crassipes (Pontederiaceae) at normal and high levels of $\mathrm{CO}_{2}$. Am. J. Bot. 78, 1459-1466 (1991).

25. Watkins, N. K., Fitter, A. H., Graves, J. D. \& Robinson, D. Carbon transfer between $\mathrm{C}_{3}$ and $\mathrm{C}_{4}$ plant linked by a common mycorrhizal network, quantified using stable carbon isotopes. Soil Biol. Biochem. 28, 471-477 (1996).

26. Waters, J. R. \& Borowicz, V. A. Effect of clipping, benomyl, and genet on ${ }^{14} \mathrm{C}$ transfer between mycorrhizal plants. Oikos 71, 246-252 (1994).

27. Tilman, D., Wedin, D. \& Knops, J. Productivity and sustainability influence biodiversity in grassland ecosystems. Nature 379, 718-720 (1996)

28. Perry, D. A., Margolis, H., Choquette, C., Molina, R. \& Trappe, J. M. Ectomycorrhizal mediation of competition between coniferous tree species. New Phytol. 112, 501-511 (1989).

29. Boutton, T. W. in Carbon Isotope Techniques (eds Coleman, D. C. \& Fry, B.) 155-170 (Academic, San Diego, 1991).

30. Warembourg, F. R. \& Kummerow, J. in Carbon Isotope Techniques (eds Coleman, D. C. \& Fry, B.) $11-$ 37 (Academic, San Diego, 1991).

Acknowledgements. We thank B. Danielson and C. Y. Li for review of the experiment designs; J. Smith and D. McKay for help with identification of ectomycorrhizal morphotypes and assistance in the greenhouse; C. Weicker and C. Gordon for assistance in the field; B. Zimonick, A. Vyse and P. G. Comeau for help and support; the staff at the Kamloops Forest Region of the British Columbia Ministry of Forest and Forestry Science Laboratory at Oregon State University for assistance; and S. Smith and R. Finlay for comments on the manuscript. This work was supported by the British Columbia Ministry of Forests an the Canada-British Columbia Partnership Agreement on Forest Resource Development (FRDA II).

Correspondence and requests for materials should be addressed to S.W.S. (e-mail: ssimard@mfor01.for gov.bc.ca).

\section{Dissociating prefrontal and} hippocampal function in episodic memory encoding

\section{R. J. Dolan ${ }^{\star} \uparrow$ \& P. C. Fletcher}

*Wellcome Department of Cognitive Neurology, Institute of Neurology, Queen Square, London WC1N 3BG, UK

$\dagger$ Royal Free Hospital School of Medicine, Roland Hill Street, London NW3, UK

Human lesion data indicate that an intact left hippocampal formation is necessary for auditory-verbal memory ${ }^{1}$. By contrast, functional neuroimaging has highlighted the role of the left prefrontal cortex ${ }^{2-4}$ but has generally failed to reveal the predicted left hippocampal activation. Here we describe an experiment involving learning category-exemplar word pairs (such as ' $\operatorname{dog}$...boxer') in which we manipulate the novelty of either individual elements or the entire category-exemplar pairing.
We demonstrate both left medial temporal (including hippocampal) and left prefrontal activation and show that these activations are dissociable with respect to encoding demands. Left prefrontal activation is maximal with a change in category-exemplar pairings, whereas medial temporal activation is sensitive to the overall degree of novelty. Thus, left prefrontal cortex is sensitive to processes required to establish meaningful connections between a category and its exemplar, a process maximized when a previously formed connection is changed. Conversely, the left medial temporal activation reflects processes that register the overall novelty of the presented material. Our results provide striking evidence of functionally dissociable roles for the prefrontal cortex and hippocampal formation during learning of auditory-verbal material.

The role of medial temporal structures, including the hippocampal and parahippocampal formation, in episodic memory is well established, with homologous left- and right-sided structures mediating verbal and visual aspects of memory, respectively ${ }^{1,5,6}$. In the monkey, lesions restricted to the hippocampus lead to striking memory impairment ${ }^{7}$. Memory processes can be fractionated into those relating to encoding (learning), consolidation (storage) and retrieval (recall). Functional neuroimaging, although failing to specify the role of the medial temporal cortex, has emphasized specific involvement of the left and right prefrontal cortices at encoding and retrieval respectively ${ }^{2-4}$. In this experiment we sought to reconcile prefrontal and hippocampal involvement in encoding by showing that hippocampal activation reflects a response to the relative novelty of sensory data whereas prefrontal activation reflects an aspect of associative semantic processing. By novelty we refer to the relative familiarity of the verbal material in the context of the experiment; associative semantic processing refers to the formation of meaningful associations between verbal items.

The study material consisted of word-paired associates comprising a category (for example, dog) and an exemplar (for example, boxer) presented auditorily. Twelve separate perfusion scans were acquired in six male subjects while they were presented with sets of 12 paired associates. The scanning window was preceded by the presentation of two sets of 12 paired associates that created the context for the critical experimental manipulation during scanning (Fig. 1). We used a design in which category and exemplar were independent factors, with two levels related to whether an item was novel (that is, not previously presented) or old (previously presented). The study thus comprised four separate conditions representing two levels of novelty (new versus old) with respect to either category or exemplar (Fig. 1). So, for example, the initial presentations of a word pair (such as dog ... boxer) during the lead-in period might be followed, during the critical scanning period, with an entirely new pair (new-new condition: for example, food ... biscuit). Alternatively, it may be followed by a change in category (new-old condition, such as sportsman ... boxer) or a change in exemplar (old-new condition: for example, dog ... labrador). In the fourth condition, subjects heard repeat presentation of pairs presented during the lead in (old-old condition; that is, dog ... boxer). Thus, in the new-new condition, the relative emphasis is on novelty, whereas in the new-old and old-new conditions, the process emphasized is the making and breaking of semantic linkages.

Activation of the left dorsolateral prefrontal cortex (DLPFC) was sensitive to a manipulation of the association between category and exemplar or vice versa. Thus, maximal activation in this region was seen in the two conditions involving a change in category exemplar pairings. Figure 2a shows a statistical parametric map (SPM) of this activation for the contrast of the two conditions (new-old and oldnew) in which there was a change in category-exemplar linkage with the condition where there was no change (old-old) $(P<0.05$, corrected). These data are shown in Fig. 2b, where the mean adjusted activity in the left DLPFC is plotted for each of the four 